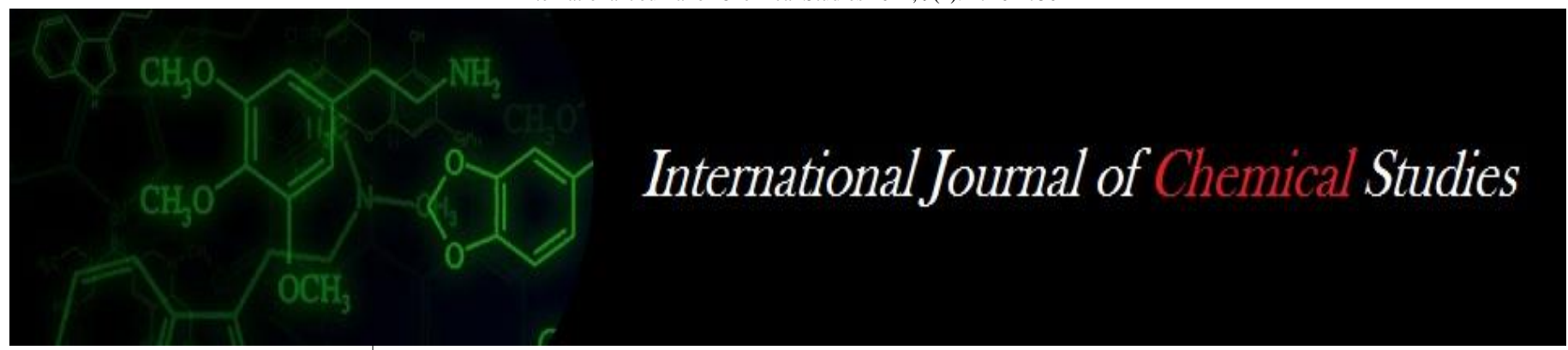

P-ISSN: 2349-8528

E-ISSN: 2321-4902

www.chemijournal.com

IJCS 2021; 9(1): 1746-1750

(C) 2021 IJCS

Received: 07-11-2020

Accepted: 17-12-2020

Karan Kumar Perumal

Department of Horticulture,

School of Agriculture, Lovely

Professional University,

Phagwara, Punjab, India

Nangunuri Varun Kumar

Department of Horticulture,

School of Agriculture, Lovely

Professional University,

Phagwara, Punjab, India

Mahantesh Kamatyanatti

Department of Horticulture,

School of Agriculture, Lovely

Professional University,

Phagwara, Punjab, India

Mamta Devi

Department of Soil Science and

Agriculture Chemistry,

SKUAST, Chatha, Jammu,

Jammu and Kashmir, India

Corresponding Author:

Karan Kumar Perumal

Department of Horticulture,

School of Agriculture, Lovely

Professional University,

Phagwara, Punjab, India

\section{Importance of various plant growth regulators in kinnow (Citrus reticulate Blanco)}

\section{Karan Kumar Perumal, Nangunuri Varun Kumar, Mahantesh Kamatyanatti and Mamta Devi}

DOI: https://doi.org/10.22271/chemi.2021.v9.i1y.11478

\begin{abstract}
Plant hormones are a tremendously imperative cause in the incorporation of development activities. Ecological factors often have inductive effects, causing changes in the metabolism and distribution of hormones in the plant. In addition, they regulate the expression of the internal genetic potential of plants. Control of gene expression has been demonstrated for phytohormones at the transcriptional and translational levels. In adding up, hormone receptors and specific binding proteins for certain hormones have been identified on the surface of the membrane. The use of the growth regulators has become an essential component of agronomic modus operands for most crops and in particular for fruit plants. So, in fruit crops, excessive fruit drop can be controlled by the exogenous application of plant growth regulators. Auxin and Gibberellins are widely used to control fruit drop and to improve fruit quality. Maturation process from fruit set to ripening and final delivery to the customer, several agents are responsible for the elimination of certain fruits from hardening to final maturity. In this review, we focus on the main functions of plant growth regulators in Kinnow mandarin production.
\end{abstract}

Keywords: Kinnow mandarin, plant growth regulators, fruit physiological growth, yield

\section{Introduction}

Citrus fruits belonging to the Rutaceae family and order Sapindales are one of the most important fruit plants of economic importance, grown worldwide, mainly because of their abundant vitamin C. Among citrus Kinnow (Citrus reticulata Blanco) is a high yielding mandarin hybrid. Widely in Punjab, India, and Pakistan (Anon 2018). It is an anti-toxic product that has excellent skin and immunity and helps lower blood pressure. It is antiinflammatory, boosts metabolism, regulates acidity and constipation, and thus balances cholesterol. Adequate plant nutrition contributes to improving the productivity and optimal quality of agricultural products (Srivastava and Singh, 2002) ${ }^{[30]}$. In India, however, horticultural crop productivity is static and per capita land is barely related to different nutrient use through the plants' roots. Therefore, the application of nutrients and growth regulator foliage can play an important role in improving fruit productivity and quality. In northwestern India, Kinnow cultivation is becoming increasingly important due to precautionary bearings and high yield potential. However, increased production reports some underlying problems, such as excessive virgin planting leading to tree destruction, high variability in fruit size, and suicidal tendency. Care should be taken when the size of the fruit is small and the percentage is high because the whole crop is consumed fresh and a large amount of fruit on the market is at a premium price. There are several reasons for small fruit size and potassium deficiency is the most important factor in regulating fruit size (Gill et al. 2005).

Low fruit sets and reduced quality of fruit are due to malnutrition, water stress, insect pest attack, and most importantly, the hormonal imbalance (Nawaz et al. 2008) ${ }^{[18]}$. The flowers and fruits on trees senescence when the concentration of auxin decreases and the concentration of ABA increases (Marinho et al. 2005).

Plant growth regulators are used in the production of citrus fruits, affect flowering, fruiting, and fruit fall, and play a major role in fruit growth and abscission. These regulators also influence fruit quality factors such as skin quality and color, fruit size, and juice quality, and are also used to improve the total soluble solids of various citrus fruits. 
This review could be a complete reduction in the potential role of substances that promote the growth of citrus physiological processes. (Harsimrat et al. 2015)

Auxin and $\mathrm{GA}_{3}$ can be used to reduce the decline of citrus fruits and improve fruit quality (Almeida et al. 2004) ${ }^{[2]}$. The foliar application of Gibberic acid can contribute to increased productivity by reducing the rate of fruit loss (Ullah et al. 2014) ${ }^{[1]}$. The foliar application of Naa (naphthalene acetate) can contribute to the reduction of the crop load, the reduction of the biennial yield, and the improvement of the fruit size and quality of different species and cultivated varieties (Guardiola et al. 2000) ${ }^{[12]}$. Researchers have suggested the use of appropriate plant growth regulators and nutrients macro and macro to curb excessive fruit loss and improve the yield and quality of citrus fruits (macro and macro). Saleem et al. (2005) ${ }^{[25]}$. may have early outcomes due to high temperature and irrigation facilities, pest attacks, and high wind speeds in the area (Ibrahim et al. 2007) ${ }^{[13]}$

Therefore, the proper use of nutrients and growth regulators to reduce premature fruit loss is strongly suggested (Modise et al. 2009) ${ }^{[16]}$.

\section{Role of the plant growth regulator}

Flowering: Citrus fruits bloom every year after completion of the juvenile period. The annual flowering of mature trees is influenced by several external and inherent factors. In citrus, like most tropical and subtropical trees, low temperatures can induce flowering (Wilkie et al. 2008). In Wenzhou Mikan, flower induction occurs in trees exposed to $15^{\circ} \mathrm{C}$ for more than 1. 5 months Nishikawa et al. (2007), trees generally remain in the vegetative growth phase until they are exposed to temperatures below $25^{\circ} \mathrm{C}$ Inoue and Harada (1998), under field conditions, trees are exposed to low temperatures in the fall, during which the induction of flowers progresses. Plant growth regulators stimulate the release of floral organs, which causes a severe drop in flowers. According to Martinez et al. (2004), when $\mathrm{GA}_{3}(20-50 \mathrm{mg} / \mathrm{L})$ was administered to all citrus fruits as a foliar application (6 $\mathrm{L}$ per tree), Hemandina flowering decreased by $25 \%$ and Orogrande flowering decreased by $60 \%$ During citrus bud development, the application of $\mathrm{GA}_{3}$ has been shown to inhibit flower production Guardiola et al. (1982) ${ }^{[19]}$, increasing the proportion of terminal flowers in leaf buds and promoting fruit development (Iglesias, et al. 2007). These results were also shown when ethical and $\mathrm{GA}_{3}$ were used to induce citrus blossoms, but $\mathrm{GA}_{3}$ had an inhibitory effect (Takahara et al. 2001).

\section{Fruit Physical characteristics}

Fruit color: Fruit color results from various treatments with $\mathrm{GA}_{3}$ showed significant results $(p<0.05)$. The untreated fruit received the highest color score $(5.0)$, but the lowest was observed for the $\mathrm{T}_{4}$ fruit $\left(\mathrm{GA}_{3}\right.$ at $\left.85 \mathrm{ppm}\right)$ (2. 66). This has also been reported by other researchers because $\mathrm{GA}_{3}$ may delay the degradation of chlorophyll and inhibits the biosynthesis and accumulation of the carotenoid Beta cryptoxanthin (Bevington et al. 1973).

Fruit Weight: Eman et al. (2007), applying $\mathrm{GA}_{3}$ at $65 \mathrm{ppm}$ shows the maximum fruit weight (196. $40 \mathrm{~g}$ ), followed by $\mathrm{GA}_{3}$ at $85 \mathrm{ppm}$, while the untreated fruit shows the minimum fruit weight (117. $53 \mathrm{~g})$. Note that spraying on wood to distort the color increases the weight of the Washington Pap Orange fruit (Eman et al. 2007).

Juice weight: Juice weight was $65 \mathrm{ppm}(325.27 \mathrm{~g})$, the highest detected in $\mathrm{GA}_{3}$. This is almost $40 \%$ higher than the control (203. 67g) all processed fruits significantly increase the weight of the juice compared to the control also that the weight of Hamlin orange juice was increased by spraying before the $\mathrm{GA}_{3}$ harvest (Davies et al. 2001).

\section{Biochemical Characteristics}

Total Soluble solids (TSS, Deg Brix): observed higher TSS in the control (10. Deg Brix), followed by $\mathrm{GA}_{3}$ at $25 \mathrm{ppm}$ (13. 65 deg Brix). Treatment with $\mathrm{GA}_{3}$ at $65 \mathrm{ppm}$ and $85 \mathrm{ppm}$ did not give good results as they are yet ripe, as they slow down the ripening of the fruit when $\mathrm{GA}_{3}$ is applied before the flower collapses (Attawia and El -Desouky, 1997). Spraying $\mathrm{GA}_{3}$ on trees in Washington has been reported to increase TSS in oranges Saleem et al. (2008) ${ }^{[24]}$, found that $10 \mathrm{ppm} \mathrm{GA}_{3}$ spray applied in the fall slows the development of skin color, leading to a reduction in TSS, sugar, and ascorbic acid Titrable acidity (\%): Ritenour et al. (2005) ${ }^{[23]}$, reported foliar application of $\mathrm{GA}_{3}$ significantly affected the acidity of Kinnow mandarin fruit, which can be titrated $(p<0.05)$. The results showed that the minimum acidity (0. 33\%) was observed at $\mathrm{GA}_{3}$ at $45 \mathrm{ppm}$ and the maximum acidity was observed in the control fruit $(0.66 \%)$. As indicated, the decrease in acidity may be due to the diluting effect of increasing water absorption by spraying $\mathrm{GA}_{3}$.

Ascorbic acid: Otmani et al. (2004), stated the content of ascorbic acid in the treated fruits was increased compared to the fruits of untreated wood (control). Maximum levels of ascorbic acid were detected with $\mathrm{GA}_{3}$ at $45 \mathrm{ppm}$ treatment $\left(50.90 \mathrm{mg} \mathrm{g}^{-1}\right)$, while the minimum levels of ascorbic acid were found in control fruits $\left(38.75 \mathrm{mg} \mathrm{g}^{-1}\right)$. Also noticed that the application of $\mathrm{GA}_{3}$ before harvest increases the content of ascorbic acid in citrus fruits.

Total phenol content: Moneruzzaman et al. $(2011)^{[17]}$, his trial show that $\mathrm{GA}_{3}$ (65 or $85 \mathrm{ppm}$ ) has the highest total phenol content (230. 74 and 229. $10 \mathrm{mg} 100 \mathrm{~g}^{-1}$, respectively) compared to $\mathrm{GA}_{3}$ (25 or $45 \mathrm{ppm}$, respectively), (220. 7 and $\left.221.74 \mathrm{mg} 100 \mathrm{~g}^{-1}\right)$. Administration of various concentrations of $\mathrm{GA}_{3}$ has been observed to significantly increase the phenol content in Syzygium samarangense.

Total antioxidant: the largest antioxidant is present at $\mathrm{GA}_{3}$ at $45 \mathrm{ppm}$ (39. 15 micro g / $100 \mathrm{~g}$ ) and the smallest antioxidant is observed at $\mathrm{GA}_{3}$ at $85 \mathrm{bppm}(29.15$ micro g/100 g), statistics. This was equivalent to $\mathrm{GA}_{3}$ at $65 \mathrm{ppm}$. This is because $\mathrm{GA}_{3}$ at $85 \mathrm{ppm}$ fruits have not yet ripened at harvest.

Total carotenoid content: Reddy and Prasad (2012) [22] investigated that applications of $\mathrm{GA}_{3}$ increase to some extent the content of carotenoids in $C$. Sinensis and C. reticulata. $\mathrm{He}$ recorded the statistics on the total carotenoid content of Kinnow fruits and showed that the maximum total carotenoid content $\left(15.90\right.$ micro $\left.\mathrm{gm}^{-1}\right)$ is observed in fruits sprayed with $\mathrm{GA}_{3}$ at $25 \mathrm{ppm}$. Fruits sprayed with $\mathrm{GA}_{3}$ at 65 and $85 \mathrm{ppm}$ showed similar values for total carotenoids (12.01 and 12.00 micro $\mathrm{GML}^{-1}$ ) respectively. The various treatments with Kinnow are affected by the administration of Gibberellic acid. This application significantly reduces the degree of staining of the fruit with Kinnow. Of all the treatments, $\mathrm{GA}_{3}$ at $25 \mathrm{ppm}$ and $45 \mathrm{ppm}$ were found to perform better in the biochemical properties of Kinnow mandarin. And have concluded that $\mathrm{GA}_{3}$ (25 or $45 \mathrm{ppm}$ ) can be used as a foliar application to improve the fruit quality of Kinnow (Waqar Shafqat et al. 2020) ${ }^{[31]}$.

Among the nutrients, potassium is one of the most essential major nutrients and varies greatly from individuals cells to xylem and depending on the plant. Potassium (K) improves the fruit size, juice content, color, size, and juice taste (Ashraf 
et al. 2010). In short, $\mathrm{K}$ improves the mineral content, yield $\mathrm{El}$ - Safty et al. (1998), and fruit quality Wei et al. (2002), of citrus fruits. Therefore, optimal K supply can have a positive impact on citrus yield, quality, and fruit loss. Similarly, deficiencies in trace elements ( $\mathrm{Zn}, \mathrm{Cu}, \mathrm{Fe}$, and $\mathrm{Mn}$ ) in soil can affect citrus yield, fruit quality, and properties of fruit yield and therefore yield (Dawood et al. 2000). Calcium is a plant for improving fruit yield and quality. Another important element of nutrition (El-Shobaky and Mohammed 2000). We have embraced on a study of the effects of micronutrient growth regulators and leaves on Kinnow yield and fruit quality.

Pradeep Singh et al. (2018), studied the effects of growth regulators and micronutrients on Kinnow yield and fruit quality. He performed nine treatments. Control (water spray), $\mathrm{NAA}$ at $100 \mathrm{ppm}, \mathrm{NAA}$ at $150 \mathrm{ppm}, \mathrm{GA}_{3}$ at $75 \mathrm{ppm}, \mathrm{GA}_{3}$ at $100 \mathrm{ppm}, \mathrm{ZnSO}_{4}$ at 0.5 percent, $\mathrm{K} 2 \mathrm{SO} 4$ at 0.1 percent, $\mathrm{K} 2 \mathrm{~S} 04$ at 0.2 percent. Application of $\mathrm{GA}_{3}$ at $100 \mathrm{ppm}$ gives the maximum plant growth (plant height, trunk circumference, canopy volume (EW/NS)and leaf area, number of fruits per tree (458), and fresh fruit yield (uptake $114.0 \mathrm{~kg}$ per trees)). Therefore, it is very important to select plant growth regulators or nutrients (macro or micro) that are suitable for foliar application on citrus trees to achieve the best potential and quality of fruit through optimal growth.

Based on VM Prasad et al. (2018) ${ }^{[9]}$, treated $\mathrm{T}_{12}\left(\mathrm{GA}_{3}\right.$ at 150 ppm) is preferred in terms of maximum plant height, canopy spread and leaf area measured in $\mathrm{cm}$. It can be concluded that it was obtained in $\left(\mathrm{cm}^{2}\right)$, number of branches /plants, stem diameter, stem length $(\mathrm{cm}) 150$ days after spraying with a plant growth regulator, flower /plants, minimum number of fruit fall/plant, average fruit weight $(\mathrm{g})$, extra length $(\mathrm{cm})$ and minimum incidence of pests, followed by $\mathrm{T}_{11}$ treatment $\left(\mathrm{GA}_{3}\right.$ at $125 \mathrm{ppm}$ ) also observed, but the smallest value was control. Studied the individual effects of plant growth regulators on the fruit and quality characteristics of Nagpur mandarin (Citrus reticulate Blanco) and showed that the application of $2,4-\mathrm{D}$ at $30 \mathrm{ppm}$ gives excellent results in terms of total soluble solids content, total acidity, TSS/acid ratio, reduced sugar, undiluted sugar, total sugar and ascorbic acid content of the fruit. With the highest sensory score, number of fruits per tree, fruit retention, yield per plant, and hectare. Maximum juice recovery and fruit weight were recorded with a 100 ppm GA 3 sprayer (M C Jain et al. 2014) ${ }^{[14]}$.

To control pre-harvest fruit fall and improve mushroom quality, only fruits have different concentrations of PGR $(2,4$ -D, NAA, GA 3 ). We evaluated the effect of falls and improve the quality of Kinnow fruits. Three sprays of PGR on Kinnow plants were given 2,4-D, NAA, GA 3 according to the concentrations of treatment from the beginning of flowering to the pre-harvest. The results showed that the physical and chemical properties of the results were superior to all others among all PGRs tested at different concentrations, so a 2,4-D at $30 \mathrm{ppm}$ was applied it increased the size of the fruit and increased the overall yield of Kinnow (Rajesh sihag et al. 2019) [26]

Pre-harvest fruit drop on the Pre-harvest drop of the fruit is of commercial loss to farmers as the drop occurs just before harvesting when fruit is physiologically mature. The growth regulators treatments $\left(2,4-\mathrm{D}, \mathrm{GA}_{3}, \mathrm{NAA}\right)$ significantly reduced the pre-harvest drop compared to control. The lowest fruit drop of 12. 955was observed in $\mathrm{T}_{3}(20 \mathrm{ppm} \mathrm{2,4-D)}$ followed by $\mathrm{T}_{2}(10 \mathrm{ppm} 2,4-\mathrm{D})$ and $\mathrm{T}_{7}\left(20 \mathrm{ppm} \mathrm{GA}_{3}\right)$ with a fruit drop of 15.02 and $16.02 \%$ whereas, the maximum fruit drop (49. 03\%) was found in Control. It is also clear from the results that 2,4-D treatments proved better compared to $\mathrm{GA}_{3}$ and NAA but when the concentrations of 2,4- D were increased up to $30 \mathrm{ppm}$, fruit drop was also increased. $\mathrm{GA}_{3}$ was at second position in controlling the pre-harvest fruit drop. They stated that their results were found to agree with that of Almedia et al. (2004) ${ }^{[2]}$, who reported that application of 2,4-D, $\mathrm{GA}_{3}$ some other plant growth regulators significantly reduced the pre-harvest fruit drop in citrus species. Keeping in view the above results it can safely be recommended that 2,4- D can be applied at $20 \mathrm{ppm}$ to control the pre-harvest fruit drop in Kinnow mandarin (Waqar Ahmad et al. 2018).

Hidayatullah Mir et al. (2017), reported frequency of application on pre-harvest fruit drop and quality of Kinnow mandarin. 2,4 -dichlorophenetic acid at $20 \mathrm{ppm}$, when sprayed three times at monthly intervals, can reduce fruit drop of Kinnow mandarin significantly when compared to the lower concentration level (10ppm) hence increasing yield and leads to improvement of some fruit quality traits and giving good returns to the growers. Therefore 2,4-D could thus be used as foliar sprays to increase fruit yield under conditions that favor provided it is applied in required quantity and appropriate growth.

(Nawaz et al. 2008) ${ }^{[18]}$ PGR effect on (fruit per plant and vitamin C) Number of fruits per plant: the study relating to the number of fruits per plant showed significant results. A maximum of 708 fruit per plant was recorded in $\mathrm{T}_{3}$ (20 PPM $2,4-\mathrm{D})$, followed by $\mathrm{T}_{9}(10 \mathrm{ppm}$ NAA $)$ and $\mathrm{T}_{9}(10 \mathrm{ppm}$ NAA) and $\mathrm{T}_{4}$ (30 PPM 2,4- D), with 686. 66 and 662 correspondingly. However, the lowest number of fruit (420. 59) was recorded in the case of the $T_{1}$ Control. Overall, Auxins (2,4-D and NAA) performed better for reducing fruit drop and increasing final crop yield than $\mathrm{GA}_{3}$. Vitamin $\mathrm{C}$ is a powerful antioxidant and is an essential part of human food. It helps save people from very serious diseases and eliminates the active oxygen species (ROS) produced in the body. The content of vitamin $\mathrm{C}$ (Ascorbic acid) in the fruit varies in the concentration of different citrus fruits. Vitamin $\mathrm{C}$ is influenced by environmental factors, fruit harvest times, plant viability, plant age, and the application of growth regulators. (M. AzherNawaz et al., 2008) ${ }^{[18]}$ reported that all the growth regulators treatments significantly increased the vitamin $\mathrm{C}$ contents of Kinnow. 2,4-D and NAA treatments proved better compared to Gibberellic acid treatments; as the concentration of Auxin (2,4-D or NAA) increases vitamin C contents also increase. Over time the concentration of Vitamin $\mathrm{C}$ increases so the fruits which are harvested earlier have less amount of Vitamin C compared to the fruits which are harvested later. Xavier et al. (2005) also observed that pre-harvest application of growth regulators increased vitamin $\mathrm{C}$ contents of the citrus fruits.

\section{Conclusion}

Plant growth regulators are versatile compounds. Uniform application of PGR (24 D, GA 3 , NAA) significantly increased the proportion of citrus mandarin fruit sets and increased the average fruit yield per plant. Fruit quality, TSS, acidity, fruit size was improved by applying PGR at low concentrations of particular and the improved fruit parameters were effectively reduced over high concentrations of particular interest is $\mathrm{GA}_{3}$ commercially in the Horticulture sector. As can be seen from the current literature, its application in the citrus spp industry especially in Kinnow $\mathrm{GA}_{3}$ application had shown many beneficial aspects in the case of Flowering, Fruit size, color TSS, TTA, Antioxidant percentage, and overall quality. The 
advantage of growth regulators is that they can be used in very low concentrations. Therefore, it does not endanger your health. However it is important to understand the basic mechanisms of growth and development of citrus to manipulate the main physiological processes and use plant growth regulators at the appropriate developmental stage and the optimal dose. Therefore, it is desirable to talk in on the study of the mechanism of action in plant growth.

\section{Reference}

1. Albaayit SFA, Abba Y, Abdullah R, Abdullah N. Evaluation of antioxidant activity and acute toxicity of Clausena excavata leaves extract. Evidence-Based Complementary and Alternative Medicine 2014.

2. Almeida IMLD, Rodrigues JD, Ono EO. Application of plant growth regulators at pre-harvest for fruit development of 'PERA' oranges. Brazilian Archives of Biology and Technology 2004;47(4):511-520.

3. Aly MA, Harhash MM, Rehab M, El-Kelawy H. Effect of foliar application with calcium, potassium and zinc treatments on yield and fruit quality of Washington navel orange trees. Middle East J Agric. Res 2015;4(3):564568.

4. Ashraf MY, Gul A, Ashraf M, Hussain F, Ebert G. Improvement in yield and quality of Kinnow (Citrus deliciosa $\mathrm{x}$ Citrus nobilis) by potassium fertilization. Journal of plant nutrition 2010;33(11):1625-1637.

5. Awad RM, El-Sayed HA, El-Razk A. Vegetative Growth and Quality of Washington Navel Orange as Affected by Shading Nets and Potassium Silicate Spraying. Egyptian Academic Journal of Biological Sciences, H. Botany 2020;11(1):81-90.

6. Bons HK, Kaur N, Rattanpal HS. Quality and quantity improvement of citrus: role of plant growth regulators. International Journal of Agriculture, Environment and Biotechnology 2015;8(2):433-447.

7. Davies FS, Zalman G. Gibberellic Acid, Fruit Freezing, and Post-freeze Quality of Hamlin 'Oranges. HortTechnology 2006;16(2):301-305.

8. Dawood SA, Hamissa AM, ELHossing AA. Response of young Washington navel orange trees grown on slightly alkaline clayey soil to foliar application of Chelated micronutrients. J Agric. Sci. Mansoura Univ 2000;25(8):5229-5240.

9. Dwivedi A, Prasad VM, Shabi M, Tripathi Y, Pandey P. Effect of plant growth regulators on growth, flowering and fruit set of 4 year old Kinnow Mandarin (Citrus reticulata Blanco.) plant. Journal of Pharmacognosy and Phytochemistry 2018;7(4):3065-3068.

10. El-Baz EET. Effect of foliar sprays of zinc and boron on leaf mineral composition, yield and fruit storability of balady mandarin trees. Mansoura Univ. Journal of Agricultural Sciences (Egypt) 2003.

11. Fahad S, Rab A. Association of gibberellic acid (GA3) with fruit set and fruit drop of sweet orange. J Biology, Agricultural and Healthcare 2014;4(2):54-59.

12. Guardiola JL, García-Luis A. Increasing fruit size in Citrus. Thinning and stimulation of fruit growth. Plant growth regulation 2000;31(1-2):121-132.

13. Ibrahim M, Ahmad N, Anwar SA, Majeed T. Effect of micronutrients on citrus fruit yield growing on calcareous soils. Advances in plant and animal boron nutrition 2007 , 179-182.

14. Jain MC, Choudhary HD, Sharma MK, Singh B. Yield and quality attributes of Nagpur mandarin as affected by use of different plant growth regulators. Environment and Ecology 2014;32(3):1141-1145.

15. Kumar A. Effect of plant growth regulators and nutrients on fruit drop and yield of Kinnow mandarin.

16. Modise DM, Likuku AS, Thuma M, Phuti R. The influence of exogenously applied 2, 4dichlorophenoxyacetic acid on fruit drop and quality of navel oranges (Citrus sinensis L.). African journal of Biotechnology 2009, 8(10).

17. Moneruzzaman KM, Hossain ABMS, Normaniza O, Boyce AN. Growth, yield and quality responses to gibberellic acid (GA 3) of Wax apple Syzygium samarangense var. Jambu air madu fruits grown under field conditions. African Journal of Biotechnology 2011;10(56):11911-11918.

18. Nawaz MA, Ahmad W, Ahmad S, Khan MM. Role of growth regulators on preharvest fruit drop, yield and quality in Kinnow mandarin. Pak. J Bot 2008;40(5):19711981.

19. Ortolá AG, Monerri C, Guardiola JL. The use of naphthalene acetic acid as a fruit growth enhancer in Satsuma mandarin: a comparison with the fruit thinning effect. Scientia horticulturae 1991;47(1-2):15-25.

20. Rattanpal HS, Rani S, Kumar A, Dhaliwal HS. Effect of potassium and 2, 4-D sprays on physical parameters of Kinnow fruits. Haryana Journal of horticultural Sciences 2005;34(3/4):222.

21. Razi MF, Khan IA, Jaskani MJ. Citrus plant nutritional profile in relation to Huanglongbing prevalence in Pakistan. Pakistan Journal of Agricultural Sciences 2011;48(4):299-304.

22. Reddy P, Prasad DM. Effect of plant growth regulators on fruit characters and yield of pomegranate (Punica granatum L) cv. Ganesh. International Journal of Plant, Animal and Environmental Sciences 2012;2(2):91-93.

23. Ritenour MA, Burton MS, McCollum TG. Effects of preor postharvest gibberellic acid application on storage quality of Florida 'FALLGLO' tangerines and 'RUBY' red grapefruit. In Proceedings of the Florida State Horticultural Society 2005;118:385-388.

24. Saleem BA, Malik AU, Pervez MA, Khan AS. Growth Regulators Application Affects Vegetative and Reproductive Behaviour of Blood Red Sweet Orange. Pak. J Bot 2008;40(5):2115-2125.

25. Saleem BA, Ziaf K, Farooq M, Ahmed W. Fruit set and drop patterns as affected by type and dose of fertilizer application in mandarin cultivars (Citrus reticulata Blanco). Int. J Agri. Biol 2005;7(6):962-965.

26. Sihag R, Bakshi M, Bhandari NS. PGR for controlling pre-harvest fruit drop and improving quality of Kinnow. Int. J Agricult. Stat. Sci 2019;15(1):231-235.

27. Singh A, Bakshi M, Brar AS, Singh SK. Effect of micronutrients in Kinnow mandarin production: A review. Int $\mathbf{J}$ Chem Stud 2019;7:5161-5164.

28. Singh P, Singh D, Singh MC, Singh S, Singh A. Impact of foliar application of growth regulators and micronutrients on fruit yield and quality of Kinnow. International Journal of Chemical Studies 2018;6(6):2545-2549.

29. Singh P, Singh D, Singh MC, Singh S, Singh A. Impact of foliar application of growth regulators and micronutrients on fruit yield and quality of Kinnow. International Journal of Chemical Studies 2018;6(6):2545-2549. 
30. Srivastava AK, Singh S. Soil analysis based diagnostic norms for Indian citrus cultivar. Communications in Soil Science and Plant Analysis 2002;33(11-12):1689-1706.

31. Talat H, Shafqat W, Qureshi MA, Sharif N, Raza MK, ud Din $\mathrm{S}$ et al. Effect of gibberellic acid on fruit quality of Kinnow mandarin. J Glob Innov Agri Soc Sci 2020;8(2):59-63.

32. Van Rensburg P, Shung-Shi P, García-Luis A, Fornes F, Guardiola JL. Improving crop value in Fino clementine mandarin with plant growth regulators. In Proc. Int. Soc. Citricult 1996;2:970-974.

33. Wei LJ, Fang C, Dongbi L, Fan WY, Bing YC, Hua WY. Effect of Application of Potassium Sulfate and Potassium Chloride on Growth of Citrus Tree, Yield and Quality of Fruits. Soil and fertilizers Beijing 2002;4:34.

34. Xiao JX, Peng SA, He HP, Li JH. Effects of calcium nitrate and IAA on calcium concentration and quality of Satsuma mandarin fruit. 果樹學報2005;22(3):211-215. 